
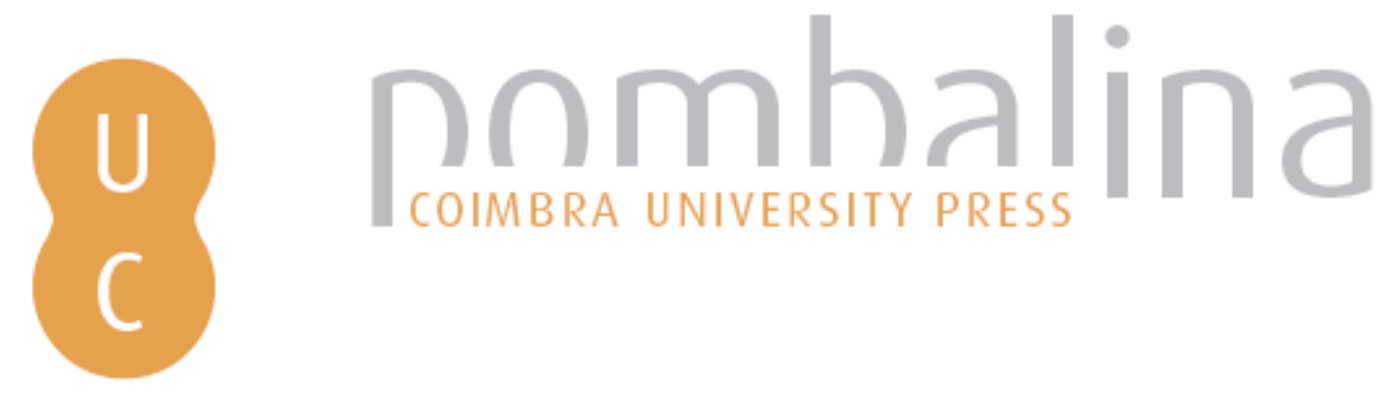

\title{
Towards more resilient and productive forest landscapes: tradeoffs in a recently burned area in Portugal
}

\author{
Benali, Akli; Barreiro, Susana; Sá, Ana; Rua, João; Page, Yannick Le; \\ Autor(es): $\quad$ Pinho, João; Fernandes, Paulo; Nunes, Silvia; Pinto, Miguel Mota; Trigo, \\ Ricardo; Camara, Carlos da; Pereira, José M. C. Cardoso \\ Publicado por: Imprensa da Universidade de Coimbra \\ URL \\ persistente: \\ URI:http://hdl.handle.net/10316.2/44684 \\ DOI: \\ DOI:https://doi.org/10.14195/978-989-26-16-506_167 \\ Accessed : $\quad$ 26-Apr-2023 16:33:18
}

A navegação consulta e descarregamento dos títulos inseridos nas Bibliotecas Digitais UC Digitalis, UC Pombalina e UC Impactum, pressupõem a aceitação plena e sem reservas dos Termos e Condições de Uso destas Bibliotecas Digitais, disponíveis em https://digitalis.uc.pt/pt-pt/termos.

Conforme exposto nos referidos Termos e Condições de Uso, o descarregamento de títulos de acesso restrito requer uma licença válida de autorização devendo o utilizador aceder ao(s) documento(s) a partir de um endereço de IP da instituição detentora da supramencionada licença.

Ao utilizador é apenas permitido o descarregamento para uso pessoal, pelo que o emprego do(s) título(s) descarregado(s) para outro fim, designadamente comercial, carece de autorização do respetivo autor ou editor da obra.

Na medida em que todas as obras da UC Digitalis se encontram protegidas pelo Código do Direito de Autor e Direitos Conexos e demais legislação aplicável, toda a cópia, parcial ou total, deste documento, nos casos em que é legalmente admitida, deverá conter ou fazer-se acompanhar por este aviso.

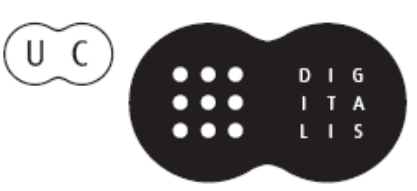




\section{ADVANCES IN}

\section{FOREST FIRE RESEARCH}

\section{8}

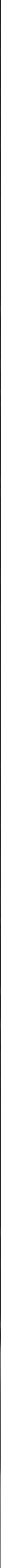


Short contribution - Fire Management

Towards more resilient and productive forest landscapes: tradeoffs in a recently burned area in Portugal

Akli Benali ${ }^{1 *}$; Susana Barreiro ${ }^{1}$; Ana Sá ${ }^{1}$; João Rua ${ }^{1}$; Yannick Le Page ${ }^{1}$; João Pinho ${ }^{2}$; Paulo Fernandes ${ }^{3}$; Silvia Nunes ${ }^{4}$; Miguel Mota Pinto ${ }^{4}$; Ricardo Trigo ${ }^{4}$; Carlos da Camara ${ }^{4}$; José M. C. Cardoso Pereira ${ }^{1}$

${ }^{I}$ Centro de Estudos Florestais, Universidade de Lisboa. Tapada da Ajuda, Lisboa (Portugal) \{aklibenali@gmail.com*\}

${ }^{2}$ Instituto da Conservação Natureza e das Florestas. Avenida da República, 16, Lisboa (Portugal)

${ }^{3}$ Centro de Investigação e Tecnologias Agroambientais e Biológicas - Universidade de Trás-os-Montes e Alto Douro. Quinta de Prados, 5001-801 Vila Real (Portugal)

${ }^{4}$ Instituto Dom Luiz, Universidade de Lisboa. Campo Grande, Ed. C1, Piso 1, Lisboa (Portugal)

Keywords: fire danger, forest planning, wood production, modelling

\section{Introduction}

On the $17^{\text {th }}$ of June of 2017 , two very large wildfires struck the centre of Portugal, burning over 47000 ha, causing 64 fatalities and a large amount of economic losses. The Alvares parish was largely affected by one of those wildfires, adding up to its large fire incidence over the last 40 years. Historically, this parish is part of a strong wood production area that has suffered significant depopulation and land abandonment since the middle of the $20^{\text {th }}$ century.

Within the context of the ongoing trend towards a drier and warmer climate in Iberia, it is necessary to consider a more resilient, yet productive, forest landscape that minimizes the negative impacts of wildfires and promotes economic revenue, crucial to avoid further land abandonment. Our objective is to assess the impact of specific fire and fuel management strategies at the landscape-level on potential changes in future landscape fire danger and wood production.

\section{Data \& Methods}

\subsection{Study Area}

Alvares parish, part of Góis municipality, was struck by a large wildfire in June 2017 that burned around $70 \%$ of its total area (10800 ha). Prior to the fire, $89 \%$ of the parish was forested, mainly with eucalypt (53\%) and maritime pine (30\%). Almost all of the forest is privately owned, the exception being a small area of municipal and communal lands managed by the National Forest Service. We extended the study region to a 55 by $55 \mathrm{~km}$ area centred in the parish to account for wildfire transmission.

\subsection{Fire Danger}

The fire danger arising from very large wildfires (>1000 ha) was estimated for the study region using the FARSITE fire modelling system. Associated weather conditions at the synoptic and mesoscale were simulated using the WRF model. Fuels were defined by reclassifying the 1990 and 2010 land cover maps into the Portuguese fuel model typology. Reported ignitions were used to derive a probability surface.

Fire danger was estimated running a large number of fire spread simulations (25000) that randomly combined weather, fuel and ignition location. The simulations were combined to create burn probability maps. Model calibration was performed by comparing outputs with the observed wildfire incidence since 1980, and tuning the adjustment factors accordingly. 


\subsection{Wood Production}

The first step was to engage private stakeholders in the characterization of general forest management approaches (FMAs) in the parish area, especially those related to eucalypt silviculture systems. Three types of manager were defined:

a) Professional owners have intensive sustainable management and carry out proper site establishment, use genetically improved material, fertilize, and perform intensive fuel and pest control operations (20\% of total area);

b) Semi-professional owners focus on site establishment operations, have no access to genetically improved material, carry out less fertilization and fuel control operations (30\%);

c) Near-absent forest owners that simply focus on stand regeneration operations and usually anticipate harvest (50\%).

A set of FMAs was defined for each forest owner type. StandsSIM.md was used to simulate the growth of eucalypt for a planning horizon of 90 years producing estimates of harvested volume.

Future forest and land use scenarios

Different scenarios regarding the future spatial organization of the landscape (involving land use and forest cover changes) and silviculture practices were defined and its impacts on fire danger and wood production were simulated and analysed. In practice, the different scenarios affect the the distribution of fuels acros the landscape.

The scenarios are described as follows:

i) The landscape/management is equivalent to the one existing prior to the 2017 fire (i.e the "business as usual" scenario - BAU);

ii) An extended network of fuel breaks is implemented, contributing to the increase of non-wooded open areas;

iii) Additionally to ii), an intensification in forest management in eucalypt stands.

The distribution of the fuels over Alvares was assigned to each scenario based on expert knowledge, information provided by stakeholders, and the land cover prior to the 2017 fire. The impact of such scenarios was assessed by evaluating changes in burn probability and harvested wood volume for the entire parish.

\section{Results}

The burn probability maps showed an overall good agreement with observed data

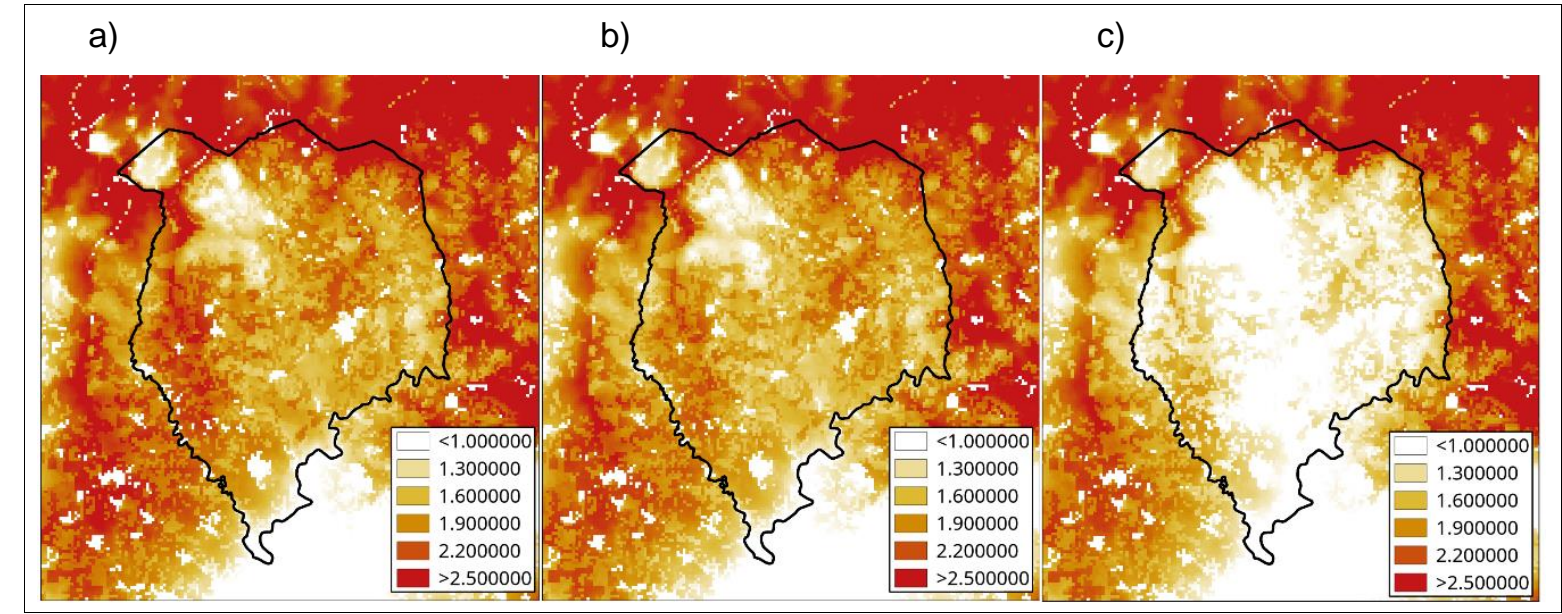

Figure 1 - Burn probability for a) Business as usual, b) Extended Fuelbreak network and c) Intensified forest management 
Results suggest that the implementation of an extended fuel break network in Alvares leads to a slight decrease in the burn probability $(\sim 10 \%)$, when compared with the BAU scenario (Fig1a,b). On the other hand, the intensification of forest management decreases burn probability by about $30 \%$ (Fig1a,c). The changes are spatially homogeneous at the parish level due to the density of the fuel break network and the large forest coverage.

The estimated harvested eucalypt volume in the BAU scenario is $1295 \times 10^{3} \mathrm{~m}^{3}$ for the 90 years horizon (Table 1). With the implementation of the fuelbreak network, eucalypt area is reduced c.a. $25 \%$, leading to an equivalent decrease in harvested volume. However, with the intensification of forest management in a small area, the reduction in harvested volume can be compensated and match 'business as usual' values.

Table 1 - Simulated Harvested wood volumes for a) Business as usual, b) Extended Fuelbreak network and c) Intensified forest management

\begin{tabular}{|l|c|c|c|c|c|c|}
\hline Scenario & \multicolumn{2}{|c|}{ Business as Usual } & \multicolumn{2}{c|}{ Fuelbreak network } & \multicolumn{2}{c|}{ Intensified management } \\
\hline $\begin{array}{l}\text { Type of } \\
\text { Management }\end{array}$ & $\begin{array}{c}\text { Area } \\
\text { (ha) }\end{array}$ & $\begin{array}{c}\text { Harvested } \\
\text { volume }\left(10^{3} \mathrm{~m}^{3}\right)\end{array}$ & $\begin{array}{c}\text { Area } \\
\text { (ha) }\end{array}$ & $\begin{array}{c}\text { Harvested } \\
\text { volume }\left(10^{3} \mathrm{~m}^{3}\right)\end{array}$ & $\begin{array}{c}\text { Area } \\
\text { (ha) }\end{array}$ & $\begin{array}{c}\text { Harvested } \\
\text { volume }\left(10^{3} \mathrm{~m}^{3}\right)\end{array}$ \\
\hline Professional & 1120 & 473 & 800 & 338 & 800 & 338 \\
\hline $\begin{array}{l}\text { Semi-Professional } \\
\text { Near- Absent }\end{array}$ & 1680 & 484 & 1200 & 346 & 3200 & 922 \\
\cline { 2 - 7 } & 2800 & 499 & 2000 & 356 & 0 & 0 \\
\hline Total & 5300 & 1295 & 4000 & 1040 & 4000 & 1260 \\
\hline
\end{tabular}

\section{Preliminary Conclusions \& On-Going Work}

A relevant change in the landscape and associated economy is required to decrease the probability of occurrence of large wildfires. Preliminary results show that the generalized increase in forest and fuel management standards can significantly decrease fire danger and stimulate the wood-based economy, leading to a more resilient, safer and still productive landscape. Work is on-going to improve the analysis of the relation between landscape resilience and economic potential, namely:

- The extension of the wood production estimates to other tree species plantations;

- Integration of the costs of implementing and maintaining fuel management areas;

- Coupling the wood production estimates with fire danger estimates;

- Suggesting wood-production zoning and conservation areas and understanding their impacts on future fire danger and harvested volume.

\section{Acknowledgments}

We acknowledge the "Observador" journal for sponsoring the project. 